\title{
The Danish database for acute and emergency hospital contacts
}

\author{
Annmarie T Lassen' \\ Henrik Jørgensen ${ }^{2}$ \\ Hanne Blæhr Jørsboe ${ }^{3,4}$ \\ Annette Odby ${ }^{5}$ \\ Mikkel Brabrand ${ }^{6}$ \\ Jacob Steinmetz ${ }^{7}$ \\ Julie Mackenhauer ${ }^{8}$ \\ Hans Kirkegaard ${ }^{8}$ \\ Christian Fynbo \\ Christiansen ${ }^{9}$
}

'Department of Emergency Medicine, Odense University Hospital, Odense, ${ }^{2}$ Department of Surgery, Hospital of Northern Sjaelland, Hilleroed, ${ }^{3}$ Department of Emergency Medicine, Nykobing F Hospital, ${ }^{4}$ Department of Hospital Administration, Nykobing F Hospital, Nykøbing Falster, ${ }^{5}$ The Danish Clinical Registers, Registry Support Centre for Health Quality and Informatics, Aarhus, ${ }^{6}$ Department of Emergency Medicine, Hospital of South West Jutland, Esbjerg, ${ }^{7}$ Department of Anaesthesia, Rigshospitalet, Copenhagen University Hospital, Copenhagen, ${ }^{8}$ Research Center for Emergency Medicine, Aarhus University, ${ }^{9}$ Department of Clinical Epidemiology, Aarhus University Hospital, Aarhus, Denmark

Correspondence: Annmarie T Lassen Department of Emergency Medicine, Odense University Hospital, Sønder Boulevard 29, 5000 Odense C, Denmark Tel +45654 I 4768

Fax +45 654I I57।

Email Annmarie.lassen@rsyd.dk
This article was published in the following Dove Press journal:

Clinical Epidemiology

25 October 2016

Number of times this article has been viewed

Aim for database: Aim of the Danish database for acute and emergency hospital contacts (DDAEHC) is to monitor the quality of care for all unplanned hospital contacts in Denmark (acute and emergency contacts).

Study population: The DDAEHC is a nationwide registry that completely covers all acute and emergency somatic hospital visits at individual level regardless of presentation site, presenting complaint, and department designation since January 1, 2013.

Main variables: The DDAEHC includes ten quality indicators - of which two are outcome indicators and eight are process indicators. Variables used to compute these indicators include among others day and time of hospital contact, vital status, ST-elevation myocardial infarction diagnosis, date and time of relevant procedure (percutaneous coronary intervention, coronary angiography, X-ray of wrist, and gastrointestinal surgery) as well as time for triage and physician judgment. Data are currently gathered from The Danish National Patient Registry, two existing databases (Danish Stroke Register and Danish Database for Emergency Surgery), and will eventually include data from the local and regional clinical logistic systems.

Descriptive data: The DDAEHC also includes age, sex, Charlson Comorbidity Index conditions, civil status, residency, and discharge diagnoses. The DDAEHC expects to include 1.7 million acute and emergency contacts per year.

Conclusion: The DDAEHC is a new database established by the Danish Regions including all acute and emergency hospital contacts in Denmark. The database includes specific outcome and process health care quality indicators as well as demographic and other basic information with the purpose to be used for enhancement of quality of acute care.

Keywords: emergency care, emergency department, mortality, rehospitalization, quality of care

\section{Background}

Danish hospitals work constantly with improvement of acute health care. Although the Danish health care system is tax-funded and provides free health care for all residents, there are variations in services offered across regions and hospitals in Denmark. ${ }^{1}$

Therefore, the Danish Regions decided in 2013 to establish a national quality database for unplanned health care contacts in hospitals in Denmark. ${ }^{2,3}$ The Danish Clinical Registers thus established the Danish database for acute and emergency hospital contacts (DDAEHC) based on principles from former national indicator databases. DDAEHC is a nationwide registry. It is one of three new databases within the area - the other two being the Danish Trauma Registry and the Prehospital Database. ${ }^{4}$ 


\section{Aim of the database}

The aim of DDAEHC is to monitor the quality of care for all unplanned hospital contacts in Denmark and thereby provide data on the evolution of acute health care.

\section{Study population}

The database covers all unplanned contacts at any somatic hospital in Denmark from January 1, 2013 and provided the first public report in 2016 covering 2013 till the first half of 2015 with an expected number of 1.7 million reported acute contacts per year. $^{5}$

DDAEHC includes any visit to a somatic emergency department as well as any somatic in-hospital ward regardless of presenting complaint and department designation (eg, internal medicine, surgery, pediatrics).

Data are gathered from The Danish National Patient Registry (DNPR), which includes all admissions to Danish hospitals since 1977 and outpatient clinic visits and emergency department visits since $1995 .{ }^{6}$ The DNPR include individual contacts, that is, if a patient is transferred between departments and/or hospitals, this will count as two or more individual contacts. The new DDAEHC merges all such related contacts into a single contact (or admission) including all individual contacts from the time of first contact to the time of discharge from latest contact in the same admission. Thus, if the patient is transferred to another department or hospital within 3 hours, these will be included within the specific admission and count as one admission (Figure 1).

Demographic data are gathered from the Danish Civil Registration System.?

\section{Main variables}

The DDAEHC includes ten quality indicators - two outcome indicators and eight process indicators (Table 1).

The first result indicator is short-term mortality within 7 days after hospital arrival and includes both inpatient and outpatient deaths, if they occur within this 7-day period. The result indicator is presented as a standardized mortality
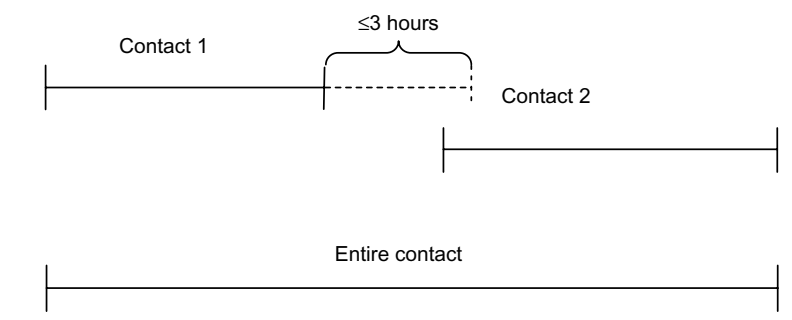

Figure I Identification of an acute patient contact - including all contacts in direct relation to the primary contact.

Note: Two contacts from different departments are considered as one contact if the time from discharge from department I to admission at department 2 is $\leq 3$ hours. ratio (SMR). The SMR is based on a risk adjustment model inspired by a UK model for 7-day mortality. ${ }^{8}$ The model was developed by a logistic regression analysis of 7-day mortality including age, sex, comorbidity (inpatient or outpatient diagnosis within each of the 19 conditions in the Charlson Comorbidity Index within 5 years prior to the current contact), and main diagnosis from current hospital contact. The SMR is computed as the observed mortality in the unit of interest divided by the expected mortality computed as the sum of each patient's estimated mortality using the prediction model.

The second result indicator is readmission within 72 hours after leaving hospital for patients with a combined index stay of $<24$ hours duration. Planned returns are not included if coded appropriately as a nonacute contact.

Using patient tracers of different clinical time-dependent conditions, four process indicators describe time from arrival until diagnosis or treatment for respectively stroke, ST-elevation myocardial infarction, suspected or confirmed perforated hollow viscera, and wrist fracture. Selected indicators from some of the disease-specific quality databases are used to supplement the broad overview of quality in the Danish acute and emergency system. Time to thrombolysis in patients with ischemic stroke is included from the Danish Stroke Register, while the other three are computed using time of treatment reported to the DNPR.

From the Danish Database for Emergency Surgery, the DDAEHC includes a fifth process indicator describing the proportion of circulatory unstable patients presenting with suspected or confirmed upper gastrointestinal peptic ulcer bleeding stabilized within 60 minutes after arrival.

Finally, three process indicators present data on patients admitted through emergency admission units. These include time to triage, time to first physician contact, and time to assessment by a specialist physician. These three indicators require data from local clinical logistic systems that are currently pending.

\section{Descriptive variables}

Besides variables used for computing quality indicators, the database includes several variables for case-mix consideration and adjustment, for example, age, sex, Charlson Comorbidity Index conditions, civil status, residency, and discharge diagnoses (Table 2). ${ }^{9}$ DDAEHC also includes the identity of the initial department with responsibility for the patient treatment during the admission; but at present, individual emergency departments and admission units cannot reliably be identified as other departments in some cases are responsible for the treatment. 
Table I Quality indicators included in the Danish database for acute hospital contacts

\begin{tabular}{|c|c|c|c|c|}
\hline No & Indicator name & Description of indicator & Type & Data source \\
\hline \multicolumn{5}{|c|}{ All acute hospital contacts } \\
\hline I & $\begin{array}{l}\text { Short-term } \\
\text { mortality }\end{array}$ & $\begin{array}{l}\text { Proportion of acute hospital contacts leading to death within } 7 \text { days after } \\
\text { first arrival at hospital. Case-mix adjusted standardized mortality ratio. }\end{array}$ & Result & DNPR, DCRS \\
\hline 2 & $\begin{array}{l}\text { Readmission after } \\
\text { short acute hospital } \\
\text { contact }\end{array}$ & $\begin{array}{l}\text { Proportion of acute hospital contacts of short duration }<24 \text { hours leading } \\
\text { to new acute hospital contact within } 72 \text { hours after leaving hospital/ } \\
\text { discharge. }\end{array}$ & Result & DNPR, DCRS \\
\hline 3 & $\begin{array}{l}\text { Time to treatment: } \\
\text { stroke }\end{array}$ & $\begin{array}{l}\text { Proportion of patients with acute ischemic stroke that are started } \\
\text { treatment with thrombolysis within I hour after arrival to hospital. }\end{array}$ & Process & DNPR, Danish Stroke Registry \\
\hline 4 & $\begin{array}{l}\text { Time to treatment: } \\
\text { ST-elevation } \\
\text { myocardial } \\
\text { infarction }\end{array}$ & $\begin{array}{l}\text { Median time from first hospital arrival to coronary angiography for } \\
\text { patients with treatment requiring STEMI upon arrival (defined as patients } \\
\text { with a STEMI diagnosis who are treated with percutaneous coronary } \\
\text { intervention within } 24 \text { hours after first hospital arrival). }\end{array}$ & Process & DNPR, regional data \\
\hline 5 & $\begin{array}{l}\text { Time to treatment: } \\
\text { perforated hollow } \\
\text { viscera }\end{array}$ & $\begin{array}{l}\text { Median time from arrival at hospital contact with a diagnosis of suspected } \\
\text { or confirmed perforated hollow viscera until surgery. }\end{array}$ & Process & DNPR \\
\hline 6 & $\begin{array}{l}\text { Time to X-ray: } \\
\text { wrist }\end{array}$ & Median time from hospital arrival to $\mathrm{X}$-ray of wrist & Process & DNPR \\
\hline 7 & $\begin{array}{l}\text { Circulatory failure/ } \\
\text { stabilization: } \\
\text { acute peptic ulcer } \\
\text { bleeding }\end{array}$ & $\begin{array}{l}\text { Proportion of patients with circulatory failure (systolic blood pressure } \\
<100 \text { and heart rate }>100 \text { ) who are brought out of this within } 60 \text { minutes } \\
\text { after arrival }\end{array}$ & Process & $\begin{array}{l}\text { DNPR, The Danish Clinical Register } \\
\text { of Emergency Surgery }\end{array}$ \\
\hline \multicolumn{5}{|c|}{ Hospital contact in admission units } \\
\hline 8 & Time to triage & Proportion of patients triaged within 30 minutes after arrival & Process & $\begin{array}{l}\text { DNPR, regional clinical logistics } \\
\text { systems }\end{array}$ \\
\hline $9 a$ & Time to physician & Proportion of patients seen by physician within 4 hours after arrival & Process & $\begin{array}{l}\text { DNPR, regional clinical logistics } \\
\text { systems }\end{array}$ \\
\hline $9 b$ & $\begin{array}{l}\text { Time to specialist } \\
\text { physician }\end{array}$ & $\begin{array}{l}\text { Proportion of patients seen and assessed by a specialist physician within } 4 \\
\text { hours }\end{array}$ & Process & $\begin{array}{l}\text { DNPR, regional clinical logistics } \\
\text { systems }\end{array}$ \\
\hline
\end{tabular}

Abbreviations: DCRS: Danish Civil Registration System; DNPR, The Danish National Patient Registry; STEMI, ST-elevation myocardial infarction.

\section{Missing data and validity}

The database largely relies on data reported from the hospitals to DNPR. If there is no registration in DNPR, it is assumed that the patient did not have a diagnosis or procedure of interest. It is therefore not possible to distinguish absence of a condition/procedure from missing values.

While DNPR and data from the Stroke Register is considered a reliable source, ${ }^{6,10-12}$ comparison with other external data sources are required to estimate the validity of some of the data. Therefore, there is an ongoing validation of the recorded time of X-ray in the DNPR compared with hospital registration and initiatives have been initiated in order to validate recorded time of percutaneous coronary intervention in DNPR as neither has been previously used in registries such as this. Currently, validity of the used time registrations as well as registration of planned return visits in the DNPR is unknown.

\section{Follow-up}

As DDAEHC is based on data from DNPR and the Danish Civil Registration System, ${ }^{6,7}$ it is continuously updated. Patients are followed for procedures performed, readmissions, and death within 7 days after arrival.

\section{Examples of research}

The database is still young. The first official report covering all acute hospital contacts from 2013 till June 30, 2015 has been released in the beginning of $2016 .{ }^{5}$

The quality indicators as provided by DDAEHC are primarily to be used to follow local performance (provided case-mix remains unchanged). As residual confounders inevitably will be present in the very diverse populations of acute patients that attend different departments, data provided by DDAEHC cannot be used to benchmark between regions, hospitals, and departments. However, the major strength of DDAEHC is complete coverage of all unscheduled hospital visits combined with demographic and disease-specific variables. This provides the possibility for a global overview of the quantity, flow, and distribution of all acute hospital contacts in Denmark.

The database provides numerous possibilities for descriptive studies of demographic characteristics of the acute hospital contacts in regions with different prehospital and in-hospital services. This could provide valuable public health - and organizational - information. Furthermore, the database can be used to assess change in quality related to 
Table 2 Variables included in the Danish database for acute hospital contacts

\begin{tabular}{|c|c|c|c|}
\hline Variable name & Description & ICD-I0 code & Procedure code \\
\hline CPR & Civil registration number & & \\
\hline PatType & Patient type & & \\
\hline ERPatient & Emergency department patient & & \\
\hline FAM & Admission unit patient & & \\
\hline FAMUnitCode & Admission unit code & & \\
\hline FAMUnitName & Admission unit name & & \\
\hline KontAars & Reason for admission & & \\
\hline HenM & Referral type & & \\
\hline HenDate & Referral date & & \\
\hline HenUnitCode & Referring department & & \\
\hline IndM & Admission type & & \\
\hline Udm & Discharge type & & \\
\hline InDateTime_tot & Date and time of first contact/admission & & \\
\hline OutDateTime_tot & Date and time of end of first contact/discharge & & \\
\hline UnitCode & Unit code & & \\
\hline DepCode & Department code & & \\
\hline HospCode & Hospital code & & \\
\hline RegCode & Region code & & \\
\hline BopRegCode & Residency region code & & \\
\hline BopKom & Residency municipality code & & \\
\hline Kom & Original municipality code & & \\
\hline AdmissionLength & Length of entire hospital contact (course) in hours & & \\
\hline ShortAdmission & Length of stay $<12$ hours & & \\
\hline WorkDay & Admission day on weekday or weekend/holiday & & \\
\hline OfficeHours & Admission daytime or nighttime & & \\
\hline NumberOfContacts & Number of individual contact in the entire contact (course) & & \\
\hline VitalStatus & Vital status & & \\
\hline StatusDate & Date of vital status & & \\
\hline CivStd & Civil status & & \\
\hline CivStatusDate & Date of civil status & & \\
\hline Age & Age (whole years) & & \\
\hline _Age_ & Age (numerical) & & \\
\hline BirthDate & Birth date & & \\
\hline Sex & Sex & & \\
\hline cprtjek & Replacement civil registration number & & \\
\hline FirstDiag & First primary diagnosis & & \\
\hline STEMI & Diagnosis of STEMI during the contact & & \\
\hline STEMIDateTime & Date and time of contact with STEMI & & \\
\hline $\mathrm{PCl}$ & $\mathrm{PCl}$ performed & & \\
\hline PCIDateTime & Date and time of $\mathrm{PCl}$ & & \\
\hline KAG & Coronary angiography performed & & \\
\hline KAGDateTime & Date and time of coronary angiography & & \\
\hline \multirow[t]{7}{*}{ Gastro } & \multicolumn{3}{|c|}{ Diagnosis of suspected or confirmed gastrointestinal perforation during the K223, $\mathrm{K} 25 \mathrm{I}, \mathrm{K} 252, \mathrm{~K} 255$, } \\
\hline & \multirow[t]{6}{*}{ contact } & $\mathrm{K} 256, \mathrm{~K} 261, \mathrm{~K} 2$ & \\
\hline & & $\mathrm{K} 266, \mathrm{~K} 28 \mathrm{I}, \mathrm{K} 2$ & \\
\hline & & $\mathrm{K} 285, \mathrm{~K} 286, \mathrm{~K} 2$ & \\
\hline & & $\mathrm{K} 272, \mathrm{~K} 275, \mathrm{~K} 2$ & \\
\hline & & K570B, K572B, & \\
\hline & & $\mathrm{K} 628 \mathrm{H}, \mathrm{K} 63 \mathrm{I}, \mathrm{K}$ & \\
\hline GastroDateTime & \multicolumn{3}{|l|}{ Date and time of suspected or confirmed gastrointestinal perforation } \\
\hline AbdominalOpr & \multicolumn{3}{|l|}{ Abdominal surgery performed } \\
\hline AbdominalOprDateTime & \multicolumn{3}{|l|}{ Date and time of abdominal surgery } \\
\hline XRayForearm & \multicolumn{3}{|l|}{ X-ray of wrist performed } \\
\hline XRayForearmDateTime & \multicolumn{3}{|l|}{ Date and time of $\mathrm{X}$-ray of wrist } \\
\hline FracDistalRadius & Distal radius (wrist) fracture & S52.5; S52.6 & \\
\hline Comorbiditet & \multicolumn{3}{|l|}{ Charlson Comorbidity Index Score } \\
\hline sl & Charlson Comorbidity Index condition: myocardial infarction & $121 ; 122 ; 123$ & \\
\hline s2 & Charlson Comorbidity Index condition: congestive heart failure & $150 ; 111.0 ; 113.0$ & \\
\hline
\end{tabular}




\begin{tabular}{|c|c|c|c|}
\hline Variable name & Description & ICD-I 0 code & Procedure code \\
\hline s3 & Charlson Comorbidity Index condition: peripheral vascular disease & I70; 17I; I72; 173; 174; I77 & \\
\hline s4 & Charlson Comorbidity Index condition: cerebrovascular disease & 160-169; G45; G46 & \\
\hline s5 & Charlson Comorbidity Index condition: dementia & F00-F03; F05.I; G30 & \\
\hline s6 & Charlson Comorbidity Index condition: chronic pulmonary disease & $\begin{array}{l}J 40-J 47 ; \text { J60-J67; J68.4; } \\
\text { J70.I; } \\
\text { J70.3; J84.I; J92.0; J96.I; } \\
\text { J98.2; J98.3 }\end{array}$ & \\
\hline s7 & Charlson Comorbidity Index condition: connective tissue disease & $\begin{array}{l}\text { M05; M06; M08; M09; } \\
\text { M30; M3I; M32; M33; } \\
\text { M34; M35; M36; D86 }\end{array}$ & \\
\hline s8 & Charlson Comorbidity Index condition: ulcer disease & $\mathrm{K} 22 . \mathrm{I} ; \mathrm{K} 25-\mathrm{K} 28$ & \\
\hline s9 & Charlson Comorbidity Index condition: mild liver disease & $\begin{array}{l}\mathrm{BI} 8 ; \mathrm{K} 70.0-\mathrm{K} 70.3 ; \mathrm{K} 70.9 \\
\mathrm{~K} 7 \mathrm{I} ; \mathrm{K} 73 ; \mathrm{K} 74 ; \mathrm{K} 76.0\end{array}$ & \\
\hline slo & Charlson Comorbidity Index condition: diabetes I and II & $\begin{array}{l}\text { EI0.0, EIO.I; EI0.9 } \\
\text { EII.0; EII.I; EII.9 }\end{array}$ & \\
\hline sll & Charlson Comorbidity Index condition: hemiplegia & G8I; G82 & \\
\hline$s 12$ & Charlson Comorbidity Index condition: moderate-to-severe renal disease & $\begin{array}{l}\text { II 2; II 3; N00-N05; N07; } \\
\text { NII; NI4; NI7-NI9; Q6I }\end{array}$ & \\
\hline s13 & Charlson Comorbidity Index condition: diabetes with end organ & $\begin{array}{l}\text { EI0.2-EI0.8 } \\
\text { EII.2-EII.8 }\end{array}$ & \\
\hline sl4 & Charlson Comorbidity Index condition: any tumor & $\mathrm{C} 00-\mathrm{C} 75$ & \\
\hline sl5 & Charlson Comorbidity Index condition: leukemia & $\mathrm{C} 9 \mathrm{I}-\mathrm{C} 95$ & \\
\hline s16 & Charlson Comorbidity Index condition: lymphoma & $\mathrm{C} 8 \mathrm{I}-\mathrm{C} 85 ; \mathrm{C} 88 ; \mathrm{C} 90 ; \mathrm{C} 96$ & \\
\hline sl7 & Charlson Comorbidity Index condition: moderate-to-severe liver disease & $\begin{array}{l}\mathrm{B} 15.0 ; \mathrm{BI} 6.0 ; \mathrm{BI} 6.2 ; \mathrm{BI} 9.0 \\
\mathrm{~K} 70.4 ; \mathrm{K} 72 ; \mathrm{K} 76.6 ; 185\end{array}$ & \\
\hline s18 & Charlson Comorbidity Index condition: metastatic solid tumor & $\mathrm{C} 76-\mathrm{C} 80$ & \\
\hline s19 & $\begin{array}{l}\text { Charlson Comorbidity Index condition: acquired immune deficiency } \\
\text { syndrome }\end{array}$ & B2I-B24 & \\
\hline Tid_laege ${ }^{a}$ & Date and time of first physician & & \\
\hline 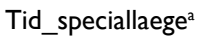 & Date and time of judgment by specialist physician & & \\
\hline Triage $^{\mathrm{a}}$ & Date and time of first triage & & \\
\hline Triageværdia & Triage value & & \\
\hline
\end{tabular}

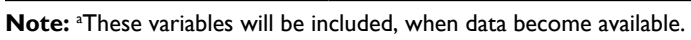

Abbreviation: ICD-10, International Classification of Diseases, I0th revision; PCl, percutaneous coronary intervention; STEMI, ST-elevation myocardial infarction.

organizational modifications ${ }^{13}$ as well as significance of time of contact (eg, day vs night and weekday vs weekend) in the acute population and for specific patient categories.

For chosen patient tracers (identified by International Classification of Diseases, 10th revision, diagnosis in the DNPR $^{6}$ ), the database can describe regional differences in organization of the acute setting for specific patients with the possibility to relate to outcome described in the database as well as other outcome defined in the studies.

\section{Administrative issues and funding}

The DDAEHC is an approved clinical quality database (Statens Serum Institut j.nr. 14/18767, the Danish Data Protection Agency j.nr 2013-58-0026).

The DDAEHC is funded by the Danish Regions and receive administrative, epidemiological, and biostatical support from The Danish Clinical Registries, Danish Regions.
Aggregated data will be reported annually in a published report, and individual-level data are provided monthly to relevant clinicians and hospital managers through each Region's information system.

\section{Conclusion}

The DDAEHC is a new database established by the Danish Regions including all acute hospital contacts in Denmark. The database includes specific outcome and process health care quality indicators as well as demographic and other basic information with the purpose to be used for enhancement of quality of acute care. The database needs to expand and qualify in the future.

\section{Acknowledgments}

This paper was funded by the Program for Clinical Research Infrastructure (PROCRIN) established by the Lundbeck 
Foundation and the Novo Nordisk Foundation and administered by the Danish Regions.

We thank statistician Henrik Nielsen for providing input to the variable list.

\section{Disclosure}

ATL is supported by an unrestricted grant given from the philanthropic fund the TRYG foundation to University of Southern Denmark.

$\mathrm{HK}$ is supported by an unrestricted grant given from the philanthropic fund the TRYG foundation to Aarhus University.

CFC is an employee of Department of Clinical Epidemiology, Aarhus University Hospital, which received funding from The Danish Clinical Registries, Danish Regions, for running the database.

The authors report no other conflicts of interest in this work.

\section{References}

1. Borger.dk [homepage on the Internet]. Public information for Danish citizens. Available from: https://www.borger.dk/Sider/Laegevagten.aspx? NavigationTaxonomyId=12803a20-31e7-4a59-96ce-b5e8ca6de580. Accessed June 9, 2015.

2. Sundhedsstyrelsen. Styrket akutberedskab-planlagningsgrundlag for det regionale sundhedsveesen [The National Board of Health: Improved Emergency Response - Suggestions for the Regional Health Services]; 2007. Available from: http://sundhedsstyrelsen.dk/publ/publ2007/plan/ akutberedskab/styrketakutberedskab.pdf. Accessed July 9, 2015.

3. Danske Regioner. Aftale om regionernes økonomi for 2015 [Danish Regions. Agreement on regional economies for 2015]; 2014. Available from: http://www.regioner.dk/ /media/Mediebibliotek_2011/ ØKONOMI/Økonomiaftaler/aftale $\% 20 \% 20$ om\%20regionernes $\% 20$ økonomi\%20for\%202015.ashx. Accessed June 9, 2015.
4. Mackenhauer J, Christiansen CF, Odby A, Jørgensen H, Lassen AT. Udvikling af kvalitetsindikatorer for akutte patientforløb på Danske Sygehuse [Development of quality indicators for acute patients in Danish Hospitals]. Danish Health Care J. 2014;7(11):4-47.

5. Databasen forAkutteHospitalskontakter. Rapport 01/01/2015-30/06/2015 [The Danish Database for Acute and Emergency Hospital Contacts. Report 01/01/2015 - 30/06/2015]. Available from: https://www.sundhed.dk/content/cms/59/67559_rapport-2015-1-databasen-for-akuttehospitalskontakter_11012016.pdf. Accessed April 4, 2016.

6. Schmidt M, Schmidt SA, Sandegaard JL, Ehrenstein V, Pedersen L, Sørensen HT. The Danish National Patient Registry: a review of content, data quality, and research potential. Clin Epidemiol. 2015;7: 449-490.

7. Schmidt M, Pedersen v, Sorensen HT. The Danish Civil Registration System as a tool in epidemiology. Eur J Epidemiol. 2014;29(8):541-549.

8. Goodacre S, Wilson R, Shephard N, Nicholl J; DAVROS Research Team. Derivation and validation of a risk adjustment model for predicting seven day mortality in emergency medical admissions: mixed prospective and retrospective cohort study. BMJ. 2012;344:e2904.

9. Dokumentation af de kliniske kvalitetsdatabaser, Danish Clinical Registries (RKKP) [homepage on the Internet]. Available from: https:// www.rkkp-dokumentation.dk/Public/Default.aspx?ReturnUrl=\%2f. Accessed April 6, 2016.

10. Thygesen SK, Christiansen CF, Christensen S, Lash TL, Sorensen HT. The predictive value of ICD-10 diagnostic coding used to assess Charlson comorbidity index conditions in the population-based Danish National Registry of Patients. BMC Med Res Methodol. 2011; 11:83.

11. Wildenschild C, Mehnert F, Thomsen RW, et al. Registration of acute stroke: validity in the Danish Stroke Registry and the Danish National Registry of patients. Clin Epidemiol. 2013;6:27-36.

12. Vest-Hansen B, Riis AH, Christiansen CF. Registration of acute medical hospital admissions in the Danish National Patient Registry: a validation study. Clin Epidemiol. 2013;5:129-133.

13. Mattsson MS, Mattsson N, Jørsboe HB. Improvement of clinical quality indicators through reorganization of the acute care by establishing an emergency department-a register study based on data from national indicators. Scand J Trauma Resusc Emerg Med. 2014; 22:60.
Clinical Epidemiology

\section{Publish your work in this journal}

Clinical Epidemiology is an international, peer-reviewed, open access, online journal focusing on disease and drug epidemiology, identification of risk factors and screening procedures to develop optimal preventative initiatives and programs. Specific topics include: diagnosis, prognosis, treatment, screening, prevention, risk factor modification,

Submit your manuscript here: https://www.dovepress.com/clinical-epidemiology-journa

\section{Dovepress}

systematic reviews, risk and safety of medical interventions, epidemiology and biostatistical methods, and evaluation of guidelines, translational medicine, health policies and economic evaluations. The manuscript management system is completely online and includes a very quick and fair peer-review system, which is all easy to use. 